\title{
Customers attitude toward Islamic mobile banking in Indonesia: Implementation of TAM
}

\author{
Alex Fahrur Riza ${ }^{1 *}$, Riza Hafizi ${ }^{2}$ \\ ${ }^{1}$ Faculty of Islamic Economics and Business, Universitas Islam Negeri Sunan \\ Kalijaga, Yogyakarta, Indonesia \\ ${ }^{2}$ Department of Islamic Banking, IAIN Palangkaraya, Palangka Raya, Indonesia \\ *Corresponding author: alex.fahrurriza7@gmail.com
}

\author{
Article History \\ Received, 28 November 2019 \\ Revised 1, 3 December 2019 \\ Revised 2, 6 December 2019 \\ Accepted, 10 December 2019
}

\begin{abstract}
Purpose: This study aims to test consumer acceptance of mobile banking Islamic banks using the Technology Acceptance Model. The concept of mobile banking is used to examine the role of banking in facilitating mobile consumer financial transactions.
\end{abstract}

Methodology: This study uses a survey with a sample of 179 users of mobile banking applications Islamic banks in Central Java and Yogyakarta. Data analysis used in this study is SEM with AMOS software assistance

Findings: All hypotheses are supported. Based on the consumer's perspective, mobile banking is an opportunity for the Islamic finance industry. However, mobile banking will transform very quickly and brought new challenges in the era of industry 4.0 .

Originality: This study enrich the discussion in the literature by retesting the technology acceptance model (TAM) to explain the usage of mobile banking of Islamic bank.

Keywords: Mobile Banking, Perceived Ease of Use, Perceived Usefulness, Attitude toward Product

\section{Cite this:}

Riza, A.F. \& Hafizi, R. (2019). Customers Attitude Toward Islamic Mobile

Banking in Indonesia: Implementation of TAM. Asian Journal of Islamic

Management, 1(2), 75-84. DOI: 10.1108/AJIM.vol1.iss2.art1

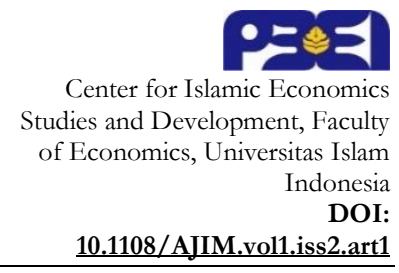

\section{Introduction}

The growing of disruptive technology innovation makes the industry and value chain model should be transformed. Initially, transactions are made manually and offline, however, now many industries are using online media and fully automated. This condition has a major impact on the financial industry (Nam et al, 2016). Banks responded to this development by creating mobile banking system, which digitalize banking transactions and traditional service into an application (Nguyen and Dang, 2017). By using technology, banking service becomes more efficient and greatly helps banks to gain a competitive advantage (Mann and Sahni, 2012).

Online banking services was firstly introduced by Stanford Federal Credit in 1994, then online banking spread rapidly throughout the world. In Indonesia, internet banking was implemented in 1998 by BII, and mobile banking was first implemented by the Bank in 2001. The use of Sharia mobile banking firstlyapplied by the Bank in 2014. Digital banking transactions are more massive after proliferation Start-Up Business in 2010 and is growing rapidly until now. The development of technology affects consumer behavior. Business competition has been a motivating factor for banks, especially Islamic banks, to continue to innovate. 
Islamic financial industry in Indonesia showed positive growth. Based on the data from the State of the Global Islamic Economy, the number of Islamic banks customers reached 12 million with the market size of USD 20 billion. In addition to the banking industry, the Sharia Non-Bank Financial Industry (IKNB) is also growing rapidly in Indonesia such as Islamic mutual funds, shares of sharia and sharia insurance. The value of takaful industry in Indonesia reached Rp 32.5 trillion. Amid all these positive developments, the level of society towards Islamic financial literacy is still low when compared to conventional finance. According to the FSA (2018), the Islamic financial literacy levels in Central Java at $11.17 \%$ and by $9.45 \%$ in Yogyakarta, it's considered highas compared to the level of a national Islamic financial literacy which is $13.77 \%$ of the entire population of Indonesia.

By current development of digital technology banking, there is an opportunity to address the issue of low level financial literacy regarding Islamic finance in Central Java and Yogyakarta. This study attempts to examine customer's attitude toward Islamic mobile banking and the level of consumer acceptance of digital banking by implementing the Technology Acceptance Model (TAM). TAM predicts user acceptance of the technology (Hu et al., 1999). The higher the perceived usefulness of the technology, the higher the level of satisfaction felt by the user. Some previous researchers focus on the factors that affect the individual in the use of new technologies, such as relative advantages, ease of use, compatibility, trialability, visibility, the results of the demonstration, and volunteerism (Moore and Benbasat, 1991; Svendsen et al., 2013).

TAM explains that the perceived ease of use (PEOU), perceived usefulness (PU), and attitude toward the product (ATP) is a factor that encourages acceptance of individuals on a product (Igbaria et al., 1995). Tech products easy to use because people like something instant and easy. Jung et al. (2015) mentioned that PEOU has a positive relationship with user satisfaction. PEOU is an important factor in influencing user perception, Besides, PEOU is also a determinant for perceived usefulness (PU). PU is a benefit or usefulness of a product to meet the needs of users. When individuals feel that mobile banking product is a product that is easy to use, they will assume that the products are useful for them (Hu et al., 1999). The perception of usefulness arises if users are able to operate mobile banking system.

The growing of Islamic finance industry followed the growing number of Muslim populations. It covers $85 \%$ of Indonesia total population. This study uses the concept of mobile banking to examine the role of banking in facilitating digital financial transactions. Therefore, this study formulates following research questions:

1. Does perceived ease of use affect the perceived usefulness of Islamic mobile banking?

2. Does perceived ease of use affect attitude toward Islamic Bank mobile banking?

3. Does perceived usefulness affect attitude toward Islamic Bank mobile banking?

This study aims to examine users perception and attitude toward Islamic banks mobile banking by using TAM model. Although previous studies have been done by researchers (Bashir and Madhavaiah, 2015; Manshour et al, 2016; Nguyen and Dang, 2018), the study on mobile banking in Islamic banking is still very few. It is because the use of mobile banking in Islamic banks is still relatively new. This study is expected to add to the wealth of literature in the study of mobile banking adoption in Islamic banking.

\section{Literature Review and Hypotheses Development}

\section{The Development of Islamic Finance}

Islamic finance is growing around the world, both in the Islamic and non-Islamic countries. In 2014, approximately 20 banks in the United Kingdom offer Islamic financial products and 49 Sukuk products with a total value of $\$ 43$ billion. Islamic financial growth is so high, reaching $50 \%$ compared to the conventional one. It has global value of $\$ 1.8$ trillion. The development of Islamic finance in Indonesia also grows significantly. 


\section{Digital Mobile Banking System}

Digital mobile banking is a new terminology in the banking industry in Indonesia and it gains a lot of attention in professional circles, consumers and academia. Digital mobile banking provides convenience for online transactions. According to Wewege (2017), digital banking is a technologybased platform for the exchange of information as well as the performance of transactions and services between banks and consumers. It covers the entire traditional banking services and operations in a digital device (Nguyen and Dang, 2018). Digital banking differs from internet banking. Internet banking services are limited to internet banking and SMS banking. Meanwhile, digital banking uses a modern operating model where all of its activities based on the digital technology.

Consumer trend in using mobile banking grows fast. Globally, more than 34 billion people ( $46 \%$ of the Earth's population) have used the internet, and the number is growing $16 \%$ per year (Internet World Stats, 2017). The use of mobile banking is quite widely by the public. In South Korea, the level of adoption reached the highest at 96\%.Singapore 94\%, Japan 83\%, China $57 \%$, Malaysia 41\%, Thailand 19\%, the Philippines 13\%, and Indonesia has the adoption rate of $36 \%$ (Nguyen and Dang, 2018).

\section{Technology Acceptance Model (TAM)}

TAM is adapted from TRA (Theory Reason Action), which specifically is used to explain technology acceptance. It was introduced by Davis in 1986. TAM explained that the intention of the individual to use information technology is determined by PU and PEOU integrated with individual attitudes (Davis, 1989). It has been widely applied to understand individual attitudes towards the use of new technology or to predict the adoption and use of information technology. TAM explains that the acceptance of new technologies is influenced by individual's belief described by two variables: PEOU and PU (Geven et al., 2003). PEOU is an indicator of the cognitive effort to learn and use information technology products. PU is a measure of the individual's subjective assessment of utility provided by new information technology products (Hu et al., 1999). Davis et al. (1989) defined PEOU as the belief that the use of mobile banking services is an easy thing to do and does not require a big effort to learn, while PU is defined as the belief that is interpreted by the level of usability in using mobile banking services. Attitude is defined as the degree of a positive or negative assessment of users in using mobile banking services.

Nam et al. (2016) stated that an important point of PEOU emphasises on the level of individual believes that the use of mobile banking is not a difficult thing, but in practice is easy to use (Davis, 1989). Furthermore, the use of mobile banking will encourage an increase in PU. Results of previous studies conducted by Wixom and Todd (2005), and Shipps \& Phillips (2012) mentioned that PEOU affects PU. Therefore, if mobile banking is easily used (PEOU), its usefulness (PU) can be felt. Thus, the first hypothesis is as follows:

H1: PEOU positively affects on PU

PEOU emphasises on the amount of effort required to use mobile banking products, while PU is the level of usability of mobile banking (Kim et al., 2016; Riza, 2019). Two of these factors are the determinants of individual attitudes toward mobile banking. Attitude toward technologies is positive or negative feelings and judgments in general when individuals using new technologies (Ajzen, 2002; Halilovic and Cicic, 2011; Wijayanti and Riza, 2017). When individual has a positive attitude toward new technological product,the intention to use it will likely to be positive too. Chuang et al. (2016) mentioned that attitude is influenced by PEOU and PU. These results are consistent with the results of research conducted by Nam et al. (2016), Wixon \& Todd (2005), and Shipps \& Phillips (2012) which stated that PEOU and PU are positively related to attitude. Improving perceived usefulness of mobile banking will improve users intentional to use technology (Davis 1986, 1989), or in this context is mobile banking. The higher the PEOU and PU of mobile banking, the higher the positive attitude toward mobile banking products. PEOU 
significantly affect attitude toward mobile banking (Chuang et al., 2016; Riza, 2019). Based on the TAM model and the results of previous studies, the authors formulate that PU and PEOU have positive effect on the attitude:

H2: PEOU positively affects the attitude toward mobile banking

H3: PU positively affects the attitude toward mobile banking

\section{Methods}

\section{Research Design}

This study uses the quantitative-survey method. The variable in this study is PEOU, PU, and the attitude toward mobile banking. This study uses primary data taken directly from the respondents. After obtaining the data, the next step is to process data using statistical tests and interpret the results (Cooper \& Schindler, 2011).

\section{Population and Sample}

The samples in this study were 179 Islamic banks customers in Central Java and Yogyakarta who use mobile banking technology. This study used purposive sampling method which is selected to obtain the respondent following the criteria established by the authors. The respondents are limited to those who had used mobile banking from Islamic banks.

\section{Method of Collecting Data}

Data were collected using an online questionnaire that is directly distributed to the respondents (Cooper and Schindler, 2011). The questionnaire used 5 points Likert scale ranging from strongly disagree to strongly agree.

\section{Operational Definitions and Items Measurement}

Technology Acceptance Model (TAM) is a construct that describes some of the factors that cause an individual to feel the benefits of using a product. TAM explained that the perceived ease of use (PEOU), perceived usefulness (PU), and attitude are factors that encourage acceptance of individuals in a product. PEOU is the ease of use of a product, $\mathrm{PU}$ is the usefulness of a product, and the attitude of the individual judgment in using a product. Each of these variables in TAM (PEOU, PU, and ATP) are measured using an instrument developed by Davis (1989) and used also by Davis et al., (1989), Mathieson (1991), and Hu et al., (1999). PU and PEOU are measured using six items of questions, while attitude is measured using three items of questions. Each variable is measured using a 5-point Likert scale.

\section{Data Analysis}

The research model is tested using Structural Equation Model (SEM). SEM is used to test the items' reliability and validity before further analysis. SEM can also be used for simultaneous model testing, making it easier for researchers to process the data and draw conclusions. The structural model is evaluated by examining the values of R2 and the size of the structural path coefficients (Hartmann et al., 2010). Through the structural model, it can be seen the level of significance and the beta value of each relationship variables to be tested so that it can be drawn conclusions related to the hypothesis.

\section{Results and Discussion}

\section{Respondents}

In total, there are 179 responses successfully collected. Demographic information of respondents in this study can be seen in Table 1 . 
Table 1. Demographics of Respondents

\begin{tabular}{lll}
\hline \multicolumn{1}{c}{ Variables } & \multicolumn{1}{c}{ Description } & Percentage (\%) \\
\hline Gender & Male & $58 \%$ \\
Age & Female & $42 \%$ \\
& $<20$ years & $4 \%$ \\
& $21-30$ years & $47 \%$ \\
& $31-40$ years & $38 \%$ \\
Work & $>40$ years & $11 \%$ \\
& Student & $20 \%$ \\
& Private employees & $43 \%$ \\
Income & Civil servants & $7 \%$ \\
& Entrepreneur & $30 \%$ \\
& $<1.5$ million & $33 \%$ \\
& $1.5-3$ million & $23 \%$ \\
& $3-6$ million & $30 \%$ \\
& $6-10$ million & $7 \%$ \\
\hline
\end{tabular}

Table 1 shows the distribution of the respondents in terms of gender, age, education, occupation, and income. In terms of age, there are $58 \%$ of male respondents and $42 \%$ of them are female. The respondents of this study are also mainly dominated by those who are aged 21-30 (47\%), and only $4 \%$ aged less than 20 years. In terms of job, as many as $43 \%$ of respondents are private employees, $30 \%$ are entrepreneurs, $20 \%$ are students and $7 \%$ are civil servants.

\section{Reliability and Validity}

Reliability and validity testing is necessary before structural model testing (Cooper and Schindler, 2011). Validity test is conducted by factor analysis, and reliability test is assessed using Cronbach $\alpha$ score. Table 2 shows that all variables in this study are reliable as the Cronbach $\alpha$ for PU is 0.912 , PEOU 0.936 and 0.886 ATP. The validity item is also considered good as all items are grouped within specified group confirming the theory. The KMO score is also good (0.941), indicating that the data is adequate.

Table 2. Factor Analysis and Results Measurement Item

\begin{tabular}{lcccl}
\hline \multicolumn{1}{c}{ Factor } & Mean & SD & $\begin{array}{c}\text { Loading } \\
\text { factor }\end{array}$ & \multicolumn{1}{c}{ Item } \\
\hline perceived usefulness & 4.99 & $1: 05$ & 0634 & M-banking allowed me to finish the job more quickly (PU1) \\
(PU) & 4.63 & $1: 03$ & 0818 & Using M-Banking can improve my performance (PU2) \\
Cronbach a: 0912 & $4: 50$ & $1: 16$ & 0800 & Using M-Banking can improve productivity I pu3) \\
& 4.91 & $1: 04$ & 0659 & Using M-Banking can improve the effectiveness of \\
& & & & activities/Business I (PU4) \\
& 4.99 & 0.91 & 0557 & Overall, M-Banking helpful in completing the work I (PU6) \\
Perceived Ease of & $4: 56$ & $1: 21$ & 0834 & Easy for Me to learn to operate the M-Banking (PEoU1) \\
Use (PEOU) & $4: 54$ & $1: 15$ & 0773 & Easy for Me to operate the M-Banking under the needs of I (PEoU2) \\
Cronbach a: 0.936 & $4: 49$ & $1: 13$ & 0840 & Easy for Me to understand the use of M-Banking (PEoU3) \\
& 4.70 & $1: 09$ & 0652 & I feel M-Banking flexible to use (PEoU4) \\
& $4: 49$ & $1: 14$ & 0718 & I am easy to master the use of M-Banking (PEoU5) \\
Attitude Toward & 4.62 & $1: 11$ & 0728 & Overall, M-Banking is easy to use (PEoU6) \\
Product (ATP) & 4.86 & $1: 05$ & 0720 & Using M-Banking for work/business I am a good idea (ATP1) \\
Cronbach a: 0.886 & 4.78 & $1: 08$ & 0762 & Using M-Banking for work/business I was the prudent thing (ATP2) \\
KMO Test & 0.941 & & & Using M-Banking provides benefits for work/Business I (ATP3) \\
Barlett's Test & 2290.354 & & & \\
Sig. & 0000 & & & \\
\hline
\end{tabular}




\section{Model and Hypothesis Testing}

The goodness of fit of the model is assessed using several indicators. The use of multiple GOF indicators allows researchers to get an acceptance of the proposed model (Hair et al., 2010, hlm.665). The size of the GOF shows how well the model derived generates a covariance matrix between the variables indicators. The GOF values in this study are as follows: Chi-square value of 191.42 minor, marginal CFI value is 0943 , the value of the marginal TLI is 0.95 , while the value of CMIN/df good that is equal to 2,587.

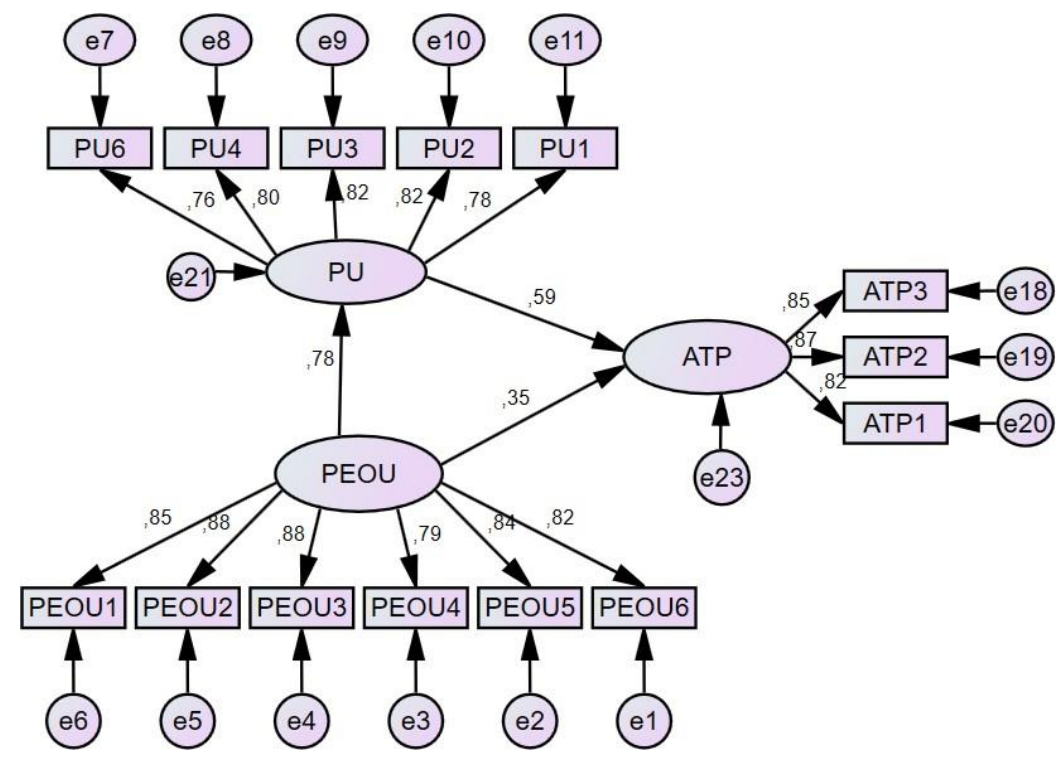

Figure 1. Structural Equation Modeling (SEM)

Table 3. Values Significance Loading and Structural Relationship Between Constructs

\begin{tabular}{lccccc}
\hline \multicolumn{1}{c}{ Effect } & Estimate & $\begin{array}{c}\text { Critical } \\
\text { Ratio }\end{array}$ & $\begin{array}{c}\text { Standardized } \\
\text { Regression }\end{array}$ & $\begin{array}{c}\text { P- } \\
\text { Value }\end{array}$ & Exp \\
\hline Perceived Ease of Use (PEOU)=of Perceived & 0.674 & 9276 & 0.785 & 0000 & Significant \\
Usefulness (PU) & & & & & \\
Perceived of Usefulness (PU) $=>$ Attitude (ATP) & 0.656 & 6015 & 0.591 & 0000 & Significant \\
Perceived Ease of Use (PEOU)=>Attitude (ATP) & 0.338 & 3,984 & 0.354 & 0000 & Significant \\
\hline
\end{tabular}

Based on the estimation using Maximum Likelihood SEM techniques, all of these hypotheses are empirically supported. As can be seen in Table 3, the value of the Standardized Regression Weight construct PEOU on PU is equal to 0.789 PU on ATP is 0591, PEOU on ATP is 0.354 . This means that all hypotheses are supported.

\section{Discussion}

This study confirms previous research on the perception of ease and perceptions of benefits on attitudes toward digital banking products. The study also measures the level of consumer acceptance of digital banking, proxied by the Technology Acceptance Model (TAM). TAM model aims to predict user acceptance to a technology (Hu et al., 1999; Svendsen et al, 2013; Chuang et al, 2016). Digital banking is generally believed to be able to affect profitability and performance (Mansour et al, 2016). Digital banking and finance have an important role in the industrial revolution 4.0 (Nguyen and Dang, 2018).

Based on data from Market Force 2015 in Wewege (2017), three main reasons consumers switch bank is because of (1) the lower cost, which is about $45 \%$, (2) not satisfied with bank 
services $36 \%$, (3) the bank does not supportive to customers. As for now, mobile banking applications have revolutionized the way consumers interact with the bank. Consumers can check balances, transfer, payment, and other services with just a mobile banking application. People love easiness, with mobile banking services will improve satisfaction. With mobile banking, transactions become more effective and efficient. This has the potential to improve the welfare of the customers because transactions can be done quickly and cheaply.

To reconfirm this, researchers gave an open question to respondents to assess their perceptions of mobile banking is used. Then, a respondent's answers are grouped by similarity/core similarity of responses. Open questions are used to explore the reasons why respondents use mobile banking. The response of various researchers classifies them into five factors, namely:

- Facilitate transaction/business (54\%)

- Effective and Efficient (by 16\%)

- Practical/Simple (15\%)

- Flexible $(6 \%)$

- Another reason (by 9\%)

The majority of respondents using digital banking because it allows a business or transaction activity, then many respondents also feel the benefits of mobile banking, such as Effective, Efficient, practical and flexible. Other interesting findings in this study were almost all respondents answered "Yes" when given the question of whether mobile banking supports the ease of doing business or my job. This means that users of digital banking in Central Java and Yogyakarta have a positive attitude towards mobile banking, Islamic banks.

Based on the consumer's perspective, it can be concluded that digital banking is an opportunity for the Islamic finance industry. But digital banking will transform very quickly and brought new challenges for the Islamic finance industry. Ito et al (2017) stated that the banking industry is transformed into six areas, namely:

- Banking Clients in 2025 namely, empowerment robot and advisor clients digitally.

- Banking Operating Models in 2025namely, banking operations will be marked with AI in terms of automation, cooperation, and industrialization.

- Banking Models Revenue 2025we will see a revenue model of banking is very new compared to the existing ones.

- Digital Banking Platforms 2025banking platform will open and can be operated from the front office to the back office.

- Data-Driven Banking 2025 database (big data) banking system will allow banks to develop new business models and products that can optimize banking processes.

- Banking Value Chain 2025 there would be no banking value chain isolated because there will be a cross-industry ecosystem.

With the rapid transformation, stakeholders in the Islamic finance industry must prepare well, and to be responsive to industry changes in 4.0 are growing very fast. Because the transformation of the bank will present a major challenge to the status quo, it means there is a greater opportunity for the Islamic financial institutions to be a market leader. To be able to take this opportunity, Islamic financial institutions must be prepared to create (1) Digital Ecosystem Bank to collaborate with business start-ups and fintech by applying Digital Banking Model. (2) Implement Digital Blockchain Bank (3) Using the Digital Custody and transaction Bank as the core of excellence (4) Increase banking capabilities based on IT infrastructure, namely the Digital Advisory Bank (Gasser et al., 2017). 


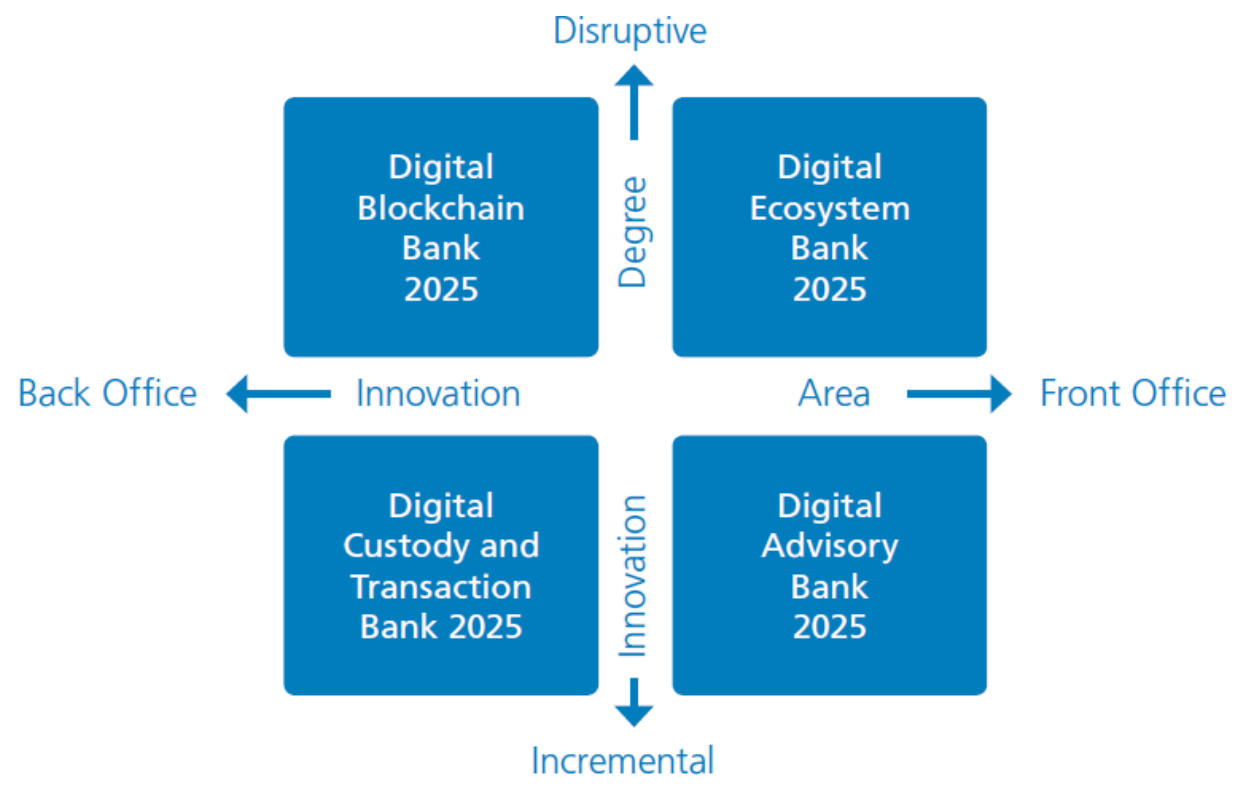

Figure 2. Digital Banking Model 2025

\section{Conclusions and Suggestions}

This research studied the perceptions and attitudes towards digital banking on Islamic banking. Researchers tried to measure the level of consumer acceptance of digital banking, proxied by the Technology Acceptance Model (TAM) introduced by Davis (1986). TAM aims to predict user acceptance of the technology.

TAM widely applied to understand individual attitudes towards the use of new technology or used to predict the adoption and use of information technology. TAM explained that the acceptance of new technologies is influenced by an individual's belief that described by two variables: PEOU and PU. PEOU an indicator of the cognitive effort required to learn and use information technology products. While PU is a measure of the individual's subjective assessment on utility provided by new information technology products.

Based on the estimation Maximum Likelihood SEM techniques, all of this hypothesis empirically supported and the third hypothesis in this study supported significantly and have a positive effect. Open questions are used to explore the reasons why respondents use mobile banking. The response of various researchers is classified into five factors, namely: 1) Ease of 2) Effective and Efficient 3) Practical 4) Flexible 5) Other factors.

Based on the consumer's perspective, digital banking is an opportunity for the Islamic finance industry. But digital banking will transform very quickly and brought new challenges. Where the banking industry is transformed into six areas, namely: 1) Banking Clients 2) Banking Operating Models 3) Banking Models Revenue 4) Banking Digital Platforms 5) Data-Driven Banking 6) Banking Value Chain.

The results of this study can be used as a reference for the Islamic finance industry stakeholders, in determining the strategy and prepare policies, to face the rapid transformation. In each of the challenges facing the Islamic financial institutions, some opportunities can be taken to be a market leader. This is because the era of disruptive not only now, but still there are eras of disruptive again in the future which promises success for its market leader. Because the transformation of the bank will present a major challenge to the status quo, it means there is a greater opportunity for the Islamic financial institutions to be a market leader. To be able to take this opportunity, Islamic financial institutions must be prepared to create innovative and creative strategies. 


\section{References}

Bashir, I. and Madhavaiah, C. (2015). Consumer attitude and behavioral intention toward the adoption of Internet banking in India. Journal of Indian Business Research. 7 (1) pp.0140.

Cooper, DR, and Schindler, PS (2011). Business Research Methods, Eleventh Edition. New York, NY: McGraw Hill.

Chuang, Li-Min, Chun-Chu Liu and Hsiao-kuang Kao. (2016). The Adoption of Fintech Service: TAM perspective. International Journal of Management and Administrative Sciences, 3 (7), pp.01-15

Davis, FD (1986). A Technology Acceptance Model for Testing empirically New End-User Information System: Theory and Results, Doctoral Dissertation, Sloan School of Management, Massachusetts Institute of Technology, Cambridge, MA.

Davis, FD (1989). Perceived Usefulness, Perceived Ease of Use, and User Acceptance of Information Technology. MIS Quarterly, 13 (3), pp.319-340.

Hu, J. Paul, Patrick YK Chau, Olivia R. Liu Sheng, and Kar Yan Tam. (1999). Examining the Technology Acceptance Model Using Physician Acceptance of Telemedicine Technology. Journal of Management Information Systems, 16 (2), pp.91-112.

Gasser, U., Gassmann, O., Hens, T., Leifer, L. Puschmann, T. and Zhao, L. (2017). Digital Banking in 2025.

Gefen, D. Elena, K., and Detmar, W. (2003). Trust and TAM in Online Shopping: An Integrated Model. MIS Quarterly, 27 (1), pp.51-90.

Igbaria, M., Guimaraes, T., and Davis, GB (1995). Testing the Determinants of Microcomputer Usage Via a Structural Equation Model. Journal of Management Information Systems, 11 (4), pp. 87-114.

Ito, J., Narula, N., and Ali, R. (2017). The Blockchain Will Do to the Financial System What the Internet Did to Media. Harvard Business Review, Digital Article. Retrieved from the Internet https://hbr.org/2017/03/the-blockchain-will-do-to-banks-and-law- firms-whatthe-did-to-media.

Internet World Stats. (2017). Internet Usage Statistics.

Jung, Young Hoon, Kim Gun, and Choong C. Lee. (2015). Factors Influencing User Satisfaction and Continuous Usage Intention on Mobile Credit Card: Based on Innovation Diffusion Theory and the Post Acceptance Model. The Journal of Society, 20 (3), pp.11-28.

Mann, BJS, and Sahni, LS (2012). Profiling adopter categories of internet banking in India: an empirical study. Vision: The Journal of Business Perspective. 16 (4), pp.283-295.

Mansour, IH Abdelgadir, AM, and Abdullah. MA (2016). Consumer attitude toward e- banking services in Islamic banks: the case of Sudan. Review of International Business and Strategy. 28 (2). Pp.1-27.

Mathieson, K. (1991). Predicting User Intention: Comparing The Technology Acceptance Model with the Theory Of Planned Behavior. Infirmation Systems Research, 2 (3), 173-191.

Moore, GC, and Benbasat, I. (1991). Development of an Instrument to Measure the Perception of Adopting an Information Technology Innovation. Information Systems Research, 2 (3), pp.192-222.

Nam, Kiheung, Zoonky Lee, and Lee Bong Gyou. (2016). How the Internet has reshaped the User Experience of the Banking Service? KSII Transactions on The Internet and 
Information Systems, 10 (2), pp.684-702.

Nguyen, TP, and Dang, TLP (2018). Digital banking in Vietnam's current situation and Recommendations. International Journal of Innovation and Research in Educational Sciences. 5 (4), pp.2349-5219.

Riza, A. F. (2019). Customer Acceptance of Digital Banking in Islamic Bank: Study on Millenial Generation. Proceeding Conference on Islamic Management Accounting and Economics, 2, pp.66-74.

Shipps, Belinda, and Brandis Phillips. (2012). Social Networks, Interactivity and Satisfaction: Assessing the Socio-Technical Behavioral Factors as an extension to the Technology Acceptance. Journal of Theoretical and Applied Electronic Commerce Research, 8 (1), pp.35-52.

Svendsen, GB, Johnsen, JK, Sorensen, LA, and Vitterso, J. (2013). Personality and Technology Acceptance: The Influence of Personality Factors on the Core Constructs of the Technology Acceptance Model. Behavior \& Information Technology, 32 (4), pp.323334.

Wewege, L. (2017). The Digital Banking Revolution: How the Financial Technology Companies Are Rapidly Transforming Retail Banking. Baby Book.

Wijayanti, D. W. \& Riza, A. F. (2017). Sharia Fintech: Positive Innovation in Consumer Perspective. International Seminar Academic Network on Competition Policy, 53(9), pp.1689-1699.

Wixom, Barbara H. \& Peter A. Todd. (2005). A theoretical Integration of User Satisfaction and Technology Acceptance. Information System Research, 16 (1), pp.85-102. 